\title{
Brainstem cavernomas: a surgical challenge
}

\author{
Cavernomas de tronco: desafio cirúrgico \\ Paulo Henrique Pires de Aguiar ${ }^{1}$, Carlos Alexandre Martins Zicarelli², Gustavo Isolan ${ }^{3}$, Ápio Antunes $^{3}$, \\ Rogério Aires ${ }^{4}$, Sérgio Murilo Georgeto ${ }^{4}$, Adriana Tahara ${ }^{5}$, Fahd Haddad ${ }^{4}$
}

\begin{abstract}
Objective: The authors show their experience with brainstem cavernomas, comparing their data with the ones of a literature review. Methods: From 1998 to 2009, 13 patients harboring brainstem cavernomas underwent surgical resection. All plain films, medical records and images were reviewed in order to sample the most important data regarding epidemiology, clinical picture, radiological findings and surgical outcomes, as well as main complications. Results: The mean age was 42.4 years (ranging from 19 to 70 ). No predominant gender: male-to-female ratio, 6:7. Pontine cases were more frequent. Magnetic resonance imaging was used as the imaging method to diagnose cavernomas in all cases. The mean follow-up was 71.3 months (range of 1 to 138 months). Clinical presentation was a single cranial nerve deficit, VIII paresis, tinnitus and hearing loss (69.2\%). All 13 patients underwent resection of the symptomatic brainstem cavernoma. Complete removal was accomplished in 11 patients. Morbidity and mortality were 15.3 and 7.6\%, respectively. Conclusions: Cavernomas can be resected safely with optimal surgical approach (feasible entry zone) and microsurgical techniques, and the goal is to remove all lesions with no cranial nerves impairment.
\end{abstract}

Keywords: Brain stem/abnormalities; Brain stem/surgery; Brain diseases; Hemangioma, cavernous

\section{RESUMO}

Objetivo: 0s autores mostram sua experiência com cavernomas de tronco cerebral, comparando seus dados com os de uma revisão da literatura. Métodos: De 1998 a 2009, 13 pacientes com cavernoma de tronco cerebral foram submetidos a ressecção cirúrgica. Todos os filmes, prontuários e imagens foram revisados para exposição dos dados mais importantes, como epidemiologia, detalhes clínicos, achados radiológicos e resultados cirúrgicos, bem como as principais complicações. Resultados: A média de idade foi de 42,4 anos (variação de 19 a 70). Não houve predominância de gênero na taxa masculino versus feminino, 6:7. Os casos pontinos foram os mais frequentes. Ressonância nuclear magnética foi o método de imagem para o diagnóstico de cavernomas em todos os casos. A média do acompanhamento foi de 71,3 meses (variação de 1 a 138 meses). A apresentação clínica mais frequente foi a paresia do VIII nervo craniano, tinitus e perda auditiva $(69,2 \%)$. Todos os 13 pacientes com cavernomas de tronco sintomáticos foram submetidos à ressecção cirúrgica. A remoção total foi realizada em 11 pacientes. A morbidade e a mortalidade foram de 15,3 e 7,6\%, respectivamente. Conclusão: Os cavernomas podem ser seguramente ressecados por meio de acessos cirúrgicos ideais (zonas de entrada seguras) e técnicas de microcirurgia, sendo que o objetivo é remover toda a lesão sem o comprometimento dos nervos cranianos.

Descritores: Tronco encefálico/anormalidades; Tronco encefálico/ cirurgia; Encefalopatias; Hemangioma cavernoso

\section{INTRODUCTION}

Cavernous malformations (CM) has long been recognized as one of the major pathologic categories of vascular malformations of the nervous system ${ }^{(1)}$. Because no abnormal vascularity is seen on angiography, CM have been included in the description of cryptic or occult vascular malformations ${ }^{(2)}$. The term used is cavernous angioma, but more recently the term "cavernous

\footnotetext{
Study carried out at Hospital Israelita Albert Einstein - HIAE, São Paulo (SP), Brazil; Hospital da Santa Casa de Londrina - Londrina (PR), Brazil; Universidade Federal do Rio Grande do Sul - UFRGS, Porto Alegre (RS), Brazil.

'Hospital Israelita Albert Einstein - HIAE, São Paulo (SP), Brazil; Neurosurgery Department, Santa Casa de Londrina - Londrina (PR), Brazil; Universidade Federal do Rio Grande do Sul - UFRGS, Rio Grande do Sul (RS), Brazil.

${ }^{2}$ Hospital Israelita Albert Einstein - HIAE, São Paulo (SP), Brasil; Neurosurgery Department, Santa Casa de Londrina - Londrina (PR), Brazil.

${ }^{3}$ Universidade Federal do Rio Grande do Sul - UFRGS, Porto Alegre (RS), Brazil.

${ }^{4}$ Neurosurgery Department, Santa Casa de Londrina - Londrina (PR), Brazil.

${ }^{5}$ Hospital Israelita Albert Einstein - HIAE, São Paulo (SP), Brazil.

Corresponding author: Paulo Henrique Pires de Aguiar - Avenida Albert Einstein, 627, consultório 1.311, 13A - Morumbi - Zip code 05652-000 - São Paulo (SP), Brazil - Phone: (11) 3747-3311 E-mail: phpaneurocir@gmail.com

Received on: Apr 15, 2011 - Accepted on: Feb 24, 2012

Conflict of interest: None
} 
malformations" has become more widely accepted, explicitly distinguishing these lesions from true vascular neoplasms as suggested by the term angioma.

$\mathrm{CM}$ of the central nervous system affects 0.4 to $0.9 \%$ of the population, and accounts for 8 to $15 \%$ of all vascular malformations ${ }^{(3)}$. In the brainstem (medulla, pons, and midbrain), its incidence is estimated to range from 9 to $35 \%$, with a predilection for the pons $s^{(4,5)}$.

Before the era of magnetic resonance imaging (MRI), brainstem CM was only diagnosed at autopsy or in surgery(6). The MRI appearance consists of a reticulated core of high and low signal intensities surrounded by a hypointense rim of hemosiderin ${ }^{(7)}$.

Digital subtraction angiography (DSA) is considered an unnecessary tool for diagnosis but it is important in deciding the strategy and approach to surgery (subtemporal, combined petrosal, or interhemispheric) ${ }^{(8)}$.

The differential diagnosis includes a very large number of conditions, such as hemorrhagic neoplasms, inflammatory lesions, and mixed lesions, capillary telangectasias, and developmental venous anomalies ${ }^{(2)}$.

The clinical symptoms of brainstem CM are related to the site of bleeding. Ocular motility and facial lesions are the most frequent deficits ${ }^{(6)}$.

Patients with asymptomatic brainstem cavernoma have a low risk of neurological events (ranging from 0.25 to $6.5 \%$ - mean of $4 \%)^{(5)}$. The risks of neurological events with surgery are greater than $10 \%$. Some authors state that surgical treatment of asymptomatic cavernomas has little or no benefit to the patient ${ }^{(6)}$.

The first neurosurgeon to operate a pontine cavernoma was Dandy, in 1928, and the indication for this surgical procedure was a pontine bleeding. Apparently the diagnosis was established only after surgery ${ }^{(7)}$. Presence or absence of bleeding, acuteness, localization, and mass effect dictate the timing of the surgery. Several technologies can be applied to the procedure, such as neuronavigation, and intraoperative ultrasound, in particular, if the lesion is too small and in a specific $\operatorname{area}^{(8)}$.

Surgery for supratentorial (and cerebellar) cavernomas in young patients with mild or non-disabling symptoms might be questionable. However, in view of the cumulative risk of bleeding or neurological disability over time, an elective surgical resection might be indicated for some of these individuals. More problematic are the lesions located either within cortical or subcortical eloquent areas and within other functionally important areas, such as basal ganglia and thalamus, or those located within the third ventricle, such as corpus callosum and cingulate gyrus, paraventricular and paratrigonal regions, and deep temporal areas. However, recent publications have demonstrated that lesions within all such locations can also be removed with safety and acceptable morbidity.

Brainstem cavernomas constitute a special entity. The hemorrhage rate of these cavernomas is up to 30 times greater than that of other locations. Due to their anatomy, the hemorrhage is more likely to cause severe neurological deficits. Brainstem cavernomas represent a formidable treatment challenge because of their location within a parenchyma that has critical neurological functions, rendering them much more difficult to remove than those in other locations.

\section{OBJECTIVE}

To present the authors' experience in brainstem cavernomas surgery, and compare it with literature data.

\section{METHODS}

We retrospectively evaluated our clinical experience from 1998 to 2009. Thirteen patients harboring brainstem cavernomas underwent surgical resection. All plain films, medical records and images were reviewed in order to sample the most important data regarding epidemiology, clinical picture, radiological findings, and surgical outcomes, as well as main complications (Chart 1).

\section{RESULTS}

\section{Patient characteristics}

The average age was 42.4 years (ranging from 19 to 70). No predominant gender: male-to-female ratio, 6:7 (Table 1). In our case series, the location was pontine in ten cases, mesencephalic in two cases, and thalamomesencephalic in one case. MRI was used as the imaging method to diagnose the cavernomas in all cases. The average follow-up was 71.3 months (ranging from 1 to 138 months). The most common clinical presentation was a single cranial nerve deficit. The most frequent main symptoms were VIII paresis - tinnitus and hearing loss $(69.2 \%)$, followed by VII paresis $(30.7 \%)$.

\section{Interventions}

All 13 patients underwent resection of the symptomatic brainstem cavernoma. Electrophysiological monitoring, including monitoring of cranial nerves and somatosensory, motor, and brainstem evoked potentials, was only used 
Chart 1. Clinical and surgical characteristics of patients with brainstem cavernomas

\begin{tabular}{|c|c|c|c|c|c|c|c|c|c|c|c|}
\hline $\mathbf{n}$ & Name & Age & Gender & Local & Removal & Approach & Clinical * & Clinical ** & & $\begin{array}{l}\text { Follow-up } \\
\text { (months) }\end{array}$ & $\begin{array}{c}\text { Rankin } \\
\text { postoperative }\end{array}$ \\
\hline 1 & AA & 40 & $M$ & Pons & Total & Retrosigmoid & VIII & VIII & - & 132 & 0 \\
\hline 2 & MN & 35 & F & Pons & Total & Retrosigmoid & VII & VII & - & 138 & 0 \\
\hline 3 & RA & 19 & $M$ & Pons & Total & Retrosigmoid & VIII, VIII & VIII & - & 120 & 0 \\
\hline 4 & $\mathrm{FA}$ & 38 & M & Pons & Total & Retrosigmoid & VI, VII, VIII & VIII & - & 96 & 0 \\
\hline 5 & $\mathrm{GP}$ & 46 & F & Pons & Total & Retrosigmoid & VIII, VIII & VII, VIII & - & 98 & 0 \\
\hline 6 & TMF & 35 & M & Pons & Total & Retrosigmoid & VIII & VIII & - & 99 & 0 \\
\hline 7 & APA & 30 & $M$ & Pons & Total & Retrosigmoid & VIII & VIII, hemiparesis & - & 62 & 0 \\
\hline 8 & $\mathrm{RS}$ & 20 & $\mathrm{~F}$ & Pons & Total & Retrosigmoid & VIII & VIII & - & 52 & 0 \\
\hline 9 & DF & 70 & F & $\begin{array}{c}\text { Thalamus- } \\
\text { mesencephalic }\end{array}$ & Total & Retrosigmoid & Motor deficit & Hemiparesis & - & 53 & 4 \\
\hline 10 & CBM & 70 & $F$ & Pons & Total & Retrosigmoid & $\mathrm{VIII}, \mathrm{XI}$ & Pseudobulbar sd & Shunt & 36 & 0 \\
\hline 11 & SR & 62 & $\mathrm{~F}$ & Mesencephalus & Total & $\begin{array}{c}\text { Infratentorial } \\
\text { supracerebellar }\end{array}$ & $\|$ & Hydrocephalus & Shunt & 28 & $5^{* * *}$ \\
\hline 12 & $\mathrm{RT}$ & 47 & $\mathrm{~F}$ & Pons & Subtotal & Retrosigmoid & VIII & VIII & - & 1 & 0 \\
\hline 13 & $\mathrm{SC}$ & 40 & M & Mesencephalus & Partial & Subtemporal & Headache & Any symptoms & - & 12 & 0 \\
\hline
\end{tabular}

Table 1. Patients, gender and complaints of cavernous malformation

\begin{tabular}{|c|c|c|c|c|}
\hline \multirow[t]{2}{*}{ Characteristics } & $\begin{array}{c}\text { All } \\
\text { patients }\end{array}$ & Midbrain & Pons & $\begin{array}{l}\text { Thalamus- } \\
\text { midbrain }\end{array}$ \\
\hline & $n=13$ & $n=2$ & $n=10$ & $n=1$ \\
\hline \multicolumn{5}{|l|}{$\operatorname{Sex} n(\%)$} \\
\hline Male & $6(46.1)$ & $1(16.7)$ & $5(83.3)$ & 0 \\
\hline Female & $7(53.9)$ & $1(14.3)$ & $5(71.4)$ & $1(14.3)$ \\
\hline \multicolumn{5}{|l|}{ Complaints n (\%) } \\
\hline Headache & $1(7.6)$ & $1(100)$ & 0 & 0 \\
\hline $\begin{array}{l}\text { Cranial nerve } \\
\text { damage }\end{array}$ & $12(92.3)$ & $1(8.4)$ & $11(91.6 \%)$ & 0 \\
\hline Hemiparesis & $1(7.6)$ & 0 & 0 & $1(100)$ \\
\hline
\end{tabular}

in one patient. The approach for pontine cavernomas (Figure 1) was the retrosigmoid approach, because most cases were more lateralized, facilitating the preservation of the seventh and eighth cranial nerves.

Complete removal was accomplished in 11 patients, and partial removal in 2 . The outcomes were directly related to the location (Figures 2 A-D and 3A-D). Morbidity and mortality rates were 15.3 and $7.6 \%$ respectively.

\section{Outcome predictors}

One patient had a poor prognosis. This patient underwent surgery for a CM in the midbrain and had acute hydrocephalus. Pneumonia evolved to sepsis, required percutaneous gastrostomy, and tracheotomy. The patient died 6 months after surgery from a general infection.

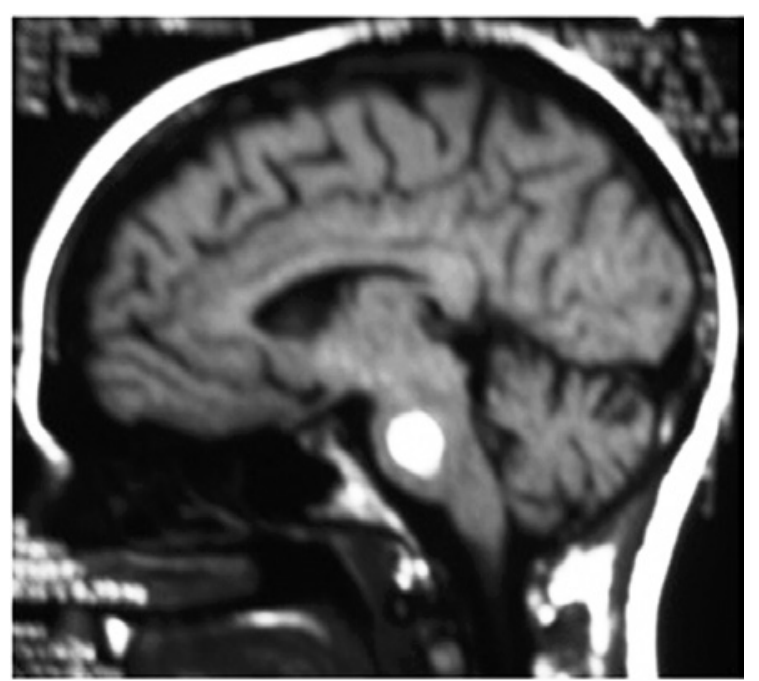

Figure 1. A 35-year-old female patient, with impairment of VII cranial nerve submitted to a retrosigmoid approach. For 2 months this impairment worsened, but improved and in fact there were no further complaints

All the other patients recovered well from surgery. At the follow-up examination, 6 months after surgery, all patients presented $100 \%$ recovery of cranial nerve impairment.

\section{DISCUSSION}

$\mathrm{CM}$ of brainstem is one the most challenging surgical procedures.

The pathological features of cavernomas are sinusoidal spaces lined by a single layer of endothelium, separated by a collagenous stroma devoid of elastin and smooth 


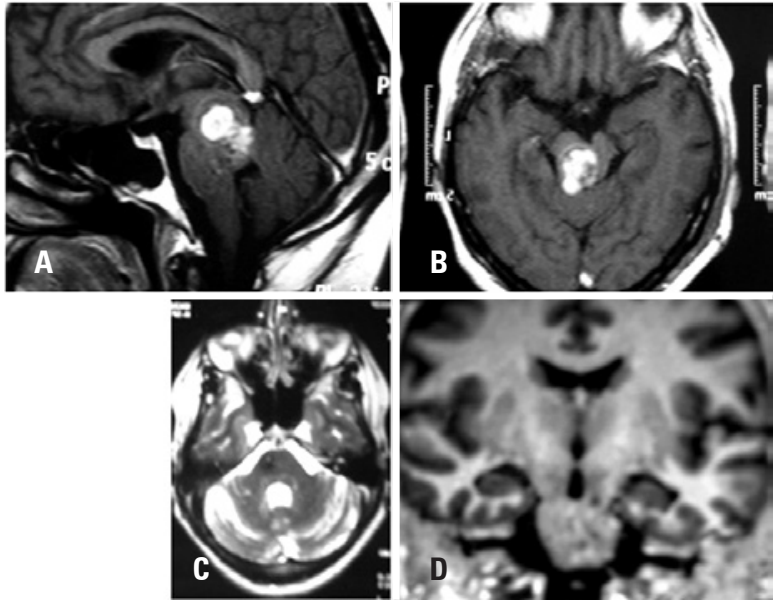

Figure 2. (A) Cavernous malformation on midbrain with III cranial nerve impairment; (B) compression on the acqueduct starting a hydrocephalus; (C) postoperative MRI without the compression of acqueduct; (D) postoperative magnetic resonance imaging. Coronal view

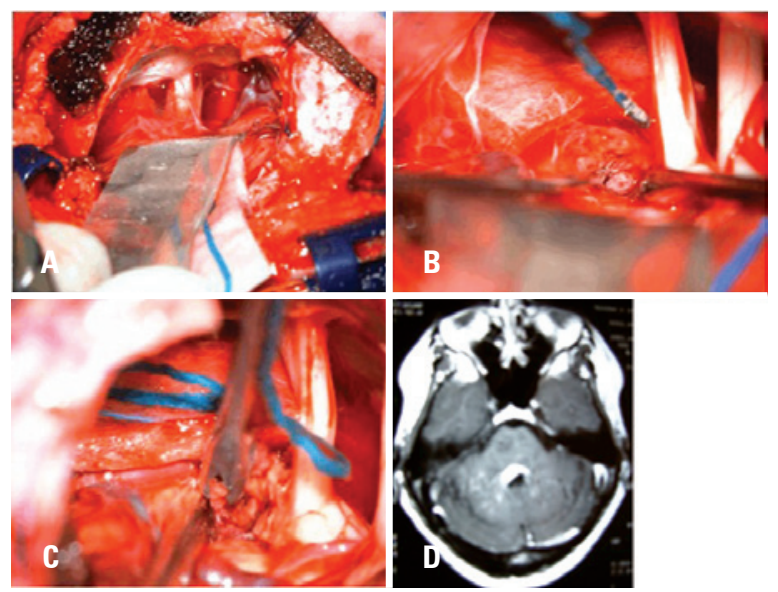

Figure 3. (A) Retrosigmoid approach; (B) surgical view of cavernoma in brainstem surface; (C) surgical resection; (D) Postoperative magnetic esonance imaging

muscle, the surrounding parenchyma consistently exhibits evidence of worsened micro-hemorrhage, hemosiderin discoloration, and hemosiderin-filled macrophages, within the lesion ${ }^{(9,10)}$. There may be hyalinization, thrombosis with varying degrees of organization, calcification, cysts, or cholesterol crystals ${ }^{(11)}$.

Cavernomas had been studied for more than 150 years, but only when MRI was introduced as a diagnostic tool, their natural history and/or indication for surgery were truly studied $^{(12)}$. In our case series, MRI was the diagnostic procedure of choice for cavernomas, but for diagnosis, head CT, MRI angiography, and CT were performed on all patients ${ }^{(13)}$. The DSA is unnecessary to establish a diagnosis of $\mathrm{CM}$, but it is very important to show the venous drainage pattern when choosing an approach - subtemporal, interhemispheric or subtemporal ${ }^{(8)}$. However, MRI angiography could be used for this. The CT scan identified hematoma formation in $48 \%$ of cases, calcification in $24 \%$, and edema in $19 \%{ }^{(13)}$. CT localized the cavernomas and their position in relation to the skull.

When the mesencephalon is involved, especially when it is located within the depth of the tegment portion, this continues to be a real challenge ${ }^{(14)}$.

Brainstem cavernomas are associated with significant focal impairment caused by hemorrhages leading to facial nerves damage ${ }^{(15)}$. Table 2 shows the clinical manifestation in the majority of series.

Brainstem CM may bleed causing catastrophic neurologic impairment due to their localization, the risk being $0.7 \%$ per year per lesion ${ }^{(24)}$. In our series, only two patients had multiple hemorrhage, and these patients had the worst modified Rankin scale (mRS) rate. The female gender had a greater risk of hemorrhage ${ }^{(5)}$. Aiba et al. shows that younger females have a greater risk of bleeding events ${ }^{(13)}$. The recovery from hemorrhage was better described by Fritschi et al. ${ }^{(14)}$. They analyzed 139 patients, 30 of whom were treated clinically, and full recovery was achieved in $43.3 \%$ of cases. Minimal disability $23.3 \%$, moderate and severe disability $6.7 \%$, and $20 \%$ mortality.

Using the retrosigmoid approach, as a rule, we observe signs of bleeding on the surface of the brainstem, and through this point we begin the dissection and removal of the cavernoma ${ }^{(8,24)}$. Ziyal et al. stated that sometimes there is no evidence of bleeding on the surface, and laterally between the V and VII nerve, the cavernoma can be accessed with a transverse incision $^{(24)}$. Through the lateral mesencephalic sulcus, and the inferior olivary nucleus, the brainstem can be reached without notable neural structure injury ${ }^{(17,25)}$. The indication to treat patients with CM include lesions that reaches a pial or ependymal surface and that may be approached without the need to reach eloquent brainstem tissues ${ }^{(17)}$. Complete microsurgical resection can be performed at a rate of $67 \%$ to $93 \%{ }^{(18)}$. The overall mortality rate is 10 to $15 \%{ }^{(17)}$. We achieved complete removal in $84.6 \%$ of cases. Chart 2 shows indications for surgery according to the literature. Chart 3 shows surgical approaches to brainstem CM.

Our patients had a preoperative mRS of 0 in $84.6 \%$ of cases, and a postoperative $\mathrm{mRS}>4$ in $15.3 \%$ of cases. In our case series, we had one death due to pulmonary sepsis, and one patient with a worsened mRS. Fritschi et al. ${ }^{(14)}$ reported $83 \%$ of patients with the same or better mRS, and $1 \%$ of mortality. Samii et al. ${ }^{(8)}$ had no deaths, and a morbidity rate of $27.7 \%$ in their series. 
Table 2. Clinical manifestation of cavernomas

\begin{tabular}{|c|c|c|c|c|c|c|}
\hline Authors & $\begin{array}{c}\text { Cases } \\
\text { (n) }\end{array}$ & $\begin{array}{c}\text { Hemorrhage } \\
\% \\
\end{array}$ & $\begin{array}{c}\text { Focal deficit } \\
\% \\
\end{array}$ & $\begin{array}{c}\text { Headache } \\
\% \\
\end{array}$ & $\begin{array}{c}\text { Raised ICP } \\
\% \\
\end{array}$ & $\begin{array}{c}\text { Incidental findings } \\
\%\end{array}$ \\
\hline Bertalanffy et al. ${ }^{(3)}$ & 72 & 20.8 & 54.1 & 20.8 & 4.1 & 4.1 \\
\hline Hsu et al. ${ }^{|5| *}$ & 664 & 13.4 & 25.4 & 6 & 0.45 & 20.6 \\
\hline Samii et al. ${ }^{(8) * *}$ & 36 & 75 & 36.1 & - & - & - \\
\hline Hauck et al..$^{(10) * *}$ & 44 & - & 57 & 32 & - & - \\
\hline Aiba et al..$^{(13) *}$ & 110 & 56 & - & - & - & 21 \\
\hline Amim-Hanjani et al. ${ }^{(16) *}$ & 94 & 70 & 44 & 16 & - & - \\
\hline Del Curling et al..177** & 32 & 9 & 22 & 34 & - & 19 \\
\hline Ferroli et al. ${ }^{(18) *}$ & 52 & - & - & - & - & - \\
\hline Porter et al..$^{(19) * *}$ & 173 & 25 & 20 & 6 & - & 12 \\
\hline Kim et al. ${ }^{(20) *}$ & 62 & 32.6 & 8.2 & 6.1 & - & 9.7 \\
\hline Kupersmith et al. ${ }^{(21) * *}$ & 37 & 73 & 27 & 43 & - & - \\
\hline Moriarity et al. ${ }^{(22) *}$ & 68 & 13 & 46 & 65 & - & 1.5 \\
\hline Moran et al. ${ }^{(23) *}$ & 296 & 7 & 5 & 1 & 2 & 4 \\
\hline Present study & 13 & 7.6 & 7.6 & 7.6 & - & - \\
\hline
\end{tabular}

* include supratentorial, ** brainstem

Chart 2. Indications for surgery in brainstem cavernomas

\begin{tabular}{|c|c|c|}
\hline Authors & $\begin{array}{l}\text { Patients } \\
\text { (n) }\end{array}$ & Indication for surgery \\
\hline Bertalanffy et al. ${ }^{(3)}$ & 72 & Hemorrhage and localization were determinant in indicating emergency, urgent, or elective surgery \\
\hline Porter et al. ${ }^{(4)}$ & 86 & $\begin{array}{l}\text { A cavernous malformation of the brainstem satisfied at least one of the following: (1) it abutted the pial surface or was exophytic, (2) it } \\
\text { produced repeated hemorrhage, causing progressive neurological deficits, (3) acute hemorrhage extending outside the lesion capsule, (4) a } \\
\text { mass effect was produced by a large intralesional hemorrhage }\end{array}$ \\
\hline Zimmerman et al. ${ }^{(6)}$ & 16 & Superficially located, symptomatic cavernomas of the brainstem \\
\hline Fahlbusch et al..$^{(7)}$ & 9 & Symptomatic brainstem hemorrhage, sudden onset of neurological damage \\
\hline Sindou et al. ${ }^{(15)}$ & 12 & $\begin{array}{l}\text { Patients were referred to surgery because of a sudden or rapidly progressive deterioration of the neurological status. All patients had one } \\
\text { or more bleeds }\end{array}$ \\
\hline Hauck et al. ${ }^{(10)}$ & 44 & Symptomatic lesions and the natural history of the lesion \\
\hline Fritschi et al. ${ }^{(14)}$ & 29 & $\begin{array}{l}\text { Lesions that become symptomatic either with a sudden onset or are attributable to a hemorrhage or a slow progressive neurological } \\
\text { impairment should be considered seriously before surgery }\end{array}$ \\
\hline Amin-Hanjani et al.!16) & 14 & Acute severe or progressive neurological deficit and recurrent hemorrhage unless deemed surgically inaccessible \\
\hline Bricolo $0^{(25)}$ & 6 & Patients with a history of progressive neurological deterioration \\
\hline Ferroli et al. ${ }^{(18)}$ & 52 & Patient presenting neurological deficit and lesion in the surface of the fourth ventricle or the lateral aspect of the brainstem \\
\hline Sakai et al. ${ }^{(26)}$ & 5 & Symptomatic lesions located near the surface of the brainstem \\
\hline Bouillot et al.(27) & 17 & All surgically treated patients were symptomatic with one or more bleeding episodes and various neurological damages \\
\hline Steinberg et al. ${ }^{(28)}$ & 42 & Multiple symptomatic clinical hemorrhage episodes or a single large hemorrhage episode associated with significant neurological deficits \\
\hline Estudo atual & 13 & Symptomatic lesions and the natural history of the lesion \\
\hline
\end{tabular}

Zimmerman et al. ${ }^{(6)}$ had one death on surgery, and the morbidity rate was $6.3 \%$. Chart 4 shows the surgical outcome in the literature.

There is no consensus on the literature as to which is the best outcome predictor: Rankin, Glasgow outcome scale, Karnofsky, or Drake scale ${ }^{(18)}$.

Stereotatic radiosurgery has been used as an alternative treatment for brainstem CM, but its use is controversial. Amim-Hanjani et al. ${ }^{(16)}$ reported a $16 \%$ incidence of permanent radiological impairment and $3 \%$ of mortality associated to radiation. Porter et al. ${ }^{(19)}$ reported $59 \%$ of temporary and $4 \%$ of permanent complications.

Why do the pontine cavernomas have a poor prognosis? Probably this is due to the proximity of the oculomotor nuclei. Motor impairment is related to circumferential 
Chart 3. Surgical approaches to brainstem cavernomas

\begin{tabular}{|c|c|c|}
\hline Authors & $\begin{array}{l}\text { Patients } \\
\text { (n) }\end{array}$ & Approaches \\
\hline Bertalanffy et al. ${ }^{(3)}$ & 72 & $\begin{array}{l}10 \text { suboccipital median, } 3 \text { suboccipital lateral retrosigmoid, } 2 \text { suboccipital lateral transcondylar, } 1 \text { occipital medial interhemisferic, } 3 \text { occipital } \\
\text { medial transtentorial, } 2 \text { temporal basal anterior, } 1 \text { combined pterional orbitozygomatic, } 2 \text { combined subtemporal retrosigmoid }\end{array}$ \\
\hline Zimmermmann et al. ${ }^{(6)}$ & 16 & $\begin{array}{l}6 \text { suboccipital midline (with } \mathrm{C} 1 \text { and C2 laminectomy in medullary lesions), } 4 \text { combined suboccipital subtemporal, } 3 \text { subtemporal, } 3 \\
\text { supracerebellar, } 1 \text { far lateral suboccipital }\end{array}$ \\
\hline Fahlbusch et al..$^{(7)}$ & 9 & 6 suboccipital midline, 2 subtemporal, supacerebellar \\
\hline Hauck et al. ${ }^{(10)}$ & 44 & 35 suboccipital, 7 pterional, 2 subtemporal \\
\hline Lekovic et al.(11) & 1 & Supracerebellar infratentorial \\
\hline Pozzati et al..$^{(12)}$ & 6 & 1 transvermian, 1 suboccipital craniectomy, 4 not mentioned (other lesions) \\
\hline Porter et al. ${ }^{(19)}$ & 86 & $\begin{array}{l}26 \text { suboccipital, } 16 \text { far lateral, } 11 \text { orbitozygomatic, } 8 \text { supracerebellar infratentorial, } 7 \text { retrosigmoid, } 5 \text { retrolabyrinthine, } 4 \text { subtemporal, } 3 \\
\text { combined supra/infratentorial, } 2 \text { pterional, } 2 \text { translabyrinthine, } 1 \text { transcochlear, } 1 \text { occipital interhemispheric }\end{array}$ \\
\hline Sakai et al. ${ }^{(26)}$ & 5 & Transvermian with midline suboccipital craniectomy, lateral suboccipital craniectomy, occipital interhemispheric transtentorial \\
\hline Bouillot et al.(27) & 17 & $\begin{array}{l}9 \text { suboccipital medial, } 4 \text { subtemporal, } 2 \text { supracerebellar infratentorial, } 1 \text { occipital transtentorial, } 1 \text { retrosigmoid, } 3 \text { occipital medial transtentorial, } \\
2 \text { temporal basal anterior, } 1 \text { combined pterional orbitozygomatic, } 2 \text { combined subtemporal retrosigmoid }\end{array}$ \\
\hline Steinberg et al. ${ }^{(28)}$ & 42 & Suboccipital midline, far lateral suboccipital, trans-sylvian, infratentorial supracerebellar, subtemporal, (interhemispheric transcallosal) \\
\hline Cantore et al. ${ }^{(29)}$ & 11 & 4 suboccipital via $4^{\text {th }}$ ventricle floor, 4 supracerebellar infratentorial, 2 subtemporal transtentorial, 1 retrosigmoid transpetrous \\
\hline Kikuta et al. ${ }^{(30)}$ & 10 & 7 midline suboccipital, 2 subtemporal, 1 occipital transtentorial \\
\hline Present study & 13 & 11 retrosigmoidal, 1 infratentorial supracerebellar, 1 subtemporal \\
\hline
\end{tabular}

Chart 4. Surgical outcome in brainstem cavernomas

\begin{tabular}{|c|c|c|}
\hline Authors & $\begin{array}{l}\text { Patients } \\
\text { (n) }\end{array}$ & Outcome \\
\hline Zimmermann et al. ${ }^{(6)}$ & 16 & 12 same or improved, 4 with new but transient deficits \\
\hline Fahlsbusch et al. ${ }^{(7)}$ & 9 & 8 improved, 1 additional morbity \\
\hline Samii et al. ${ }^{(8)}$ & 36 & 12 hemihypoesthesia, 5 internuclear ophthalmoplegia, 3 hemiparesis, 16 same \\
\hline Hauck et al. ${ }^{(10)}$ & 44 & 6 cranial nerve dysfunction, 4 hydrocephalus, 3 worsening hemiparesis, 2 new deafness, 1 subacute meningitis \\
\hline Lekovic et al.(11) & 1 & Hemiparesis \\
\hline Pozzati et al..$^{[12\}}$ & 6 & 1 diplopia, facial hypesthesia and gait ataxia, 1 same, 4 not mentioned (another lesions) \\
\hline Fritschi et al. ${ }^{(14)}$ & 93 & $39.8 \%$ complete recovery, $44.1 \%$ minimally disable, $15 \%$ moderately disable, $1.1 \%$ severely disable \\
\hline Amin-Hanjani et al. ${ }^{(16)}$ & 14 & $64.2 \%$ Excellent or good, 35.8\% fair to poor, 1 death \\
\hline Porter et al. ${ }^{(19)}$ & 86 & 61 good recovery, 14 moderate disability, 5 severe disability, 1 persistent vegetative state, 3 deaths \\
\hline Sakai et al. ${ }^{(26)}$ & 5 & All improved \\
\hline Bouillot et al. ${ }^{(27)}$ & 17 & 10 improved neurologically, 2 unchanged, 3 worsened, 2 deaths \\
\hline Steinberg et al. ${ }^{(28)}$ & 42 & $43 \%$ improved, $52 \%$ unchanged, $5 \%$ worsened \\
\hline Cantore et al. ${ }^{(29)}$ & 11 & 3 oculomotor deficits, 3 facial nerve deficits, 3 VP shunts, 1 death \\
\hline Present study & 13 & 9 same, 1 hydrocephaly, 1 pseudobulbar sd, 1 improved \\
\hline
\end{tabular}

VP: Ventriculoperitoneal.

perforatored arteries that emerge from the posterior cerebral artery.

\section{What are the best surgical approaches?}

The anterior portion of mesencephalus and the interpeduncular fossa tissue may be accessed via subtemporal and retrosigmoidal approach to the posterior portion. However, the posterior portion is better accessed via supracerebellar infratentorial approach, in a semi-sitting portion. We preferred the retrosigmoid approach because it is more used due to the best view to the safety entry zones.

Somatosensory evoked potential should be used in all patients in order to avoid nuclear and long tract damage ${ }^{(20)}$.

The timing of the brainstem cavernous surgery should consider the symptoms, and nuclear signs, as well as the presence of acute symptoms ${ }^{(21-30)}$. In our opinion, extension and volume of hematoma are 
factors that should be considered before a surgery is indicated.

\section{CONCLUSION}

Cavernomas can be resected safely with optimal surgical approach (feasible entry zone) and microsurgical techniques. Factors that affect the outcome during surgery are preoperative status, size, timing of operation and complete resection. The goal of surgical intervention should be the complete resection of the lesion without any neurological impairment.

\section{REFERENCES}

1. McCormick WF. The pathology of vascular ("arteriovenous") malformations. J Neurosurg. 1966;24(4):807-16.

2. Wilkins RH. Natural history of intracranial vascular malformations: a review. Neurosurgery. 1985;16(3):421-30.

3. Bertalanffy H, Benes L, Miyazawa T, Alberti 0, Siegel AM, Sure U. Cerebral cavernomas in the adult. Review of the literature and analysis of 72 surgically treated patients. Neurosurg Rev. 2002;25(1-2):1-53.

4. Porter RW, Detwiler PW, Spetzler RF, Lawton MT, Baskin JJ, Derksen PT, et al Cavernous malformations of the brainstem: Experience with 100 patients. J Neurosurg. 1999;90(1):50-8.

5. Hsu FP, Rigamonti D, Huhn SL. Epidemiology of cavernous malformatios. In: Award IA, Barrow DL, editors. Cavernous malformations. Park Ridge: AANS; 1993. p. 13-23.

6. Zimmerman RS, Spetzler RF, Lee KS, Zabramski JM, Hargraves RW. Cavernous malformations of the brain stem. J Neurosurg. 1991;75(1):32-9.

7. Fahlbusch R, Strauss $C$. [Surgical significance of cavernous hemangioma of the brain stem]. Zentralbl Neurochir. 1991;52(1):25-32. Article in German.

8. Samii M, Eghbal R, Carvalho GA, Matthies C. Surgical management of brainstem cavernomas. J Neurosurg. 2001;95(5):825-32.

9. Bertalanffy H, Kuhn G, Scheremet R, Seeger W. Indications for surgery and prognosis in patients with cerebral cavernous angiomas. Neurol Med Chir (Tokyo). 1992;32(9):659-66.

10. Hauck EF, Barnett SL, White JA, Samson D. Symptomatic brainstem cavernomas, Neurosurgery. 2009;64(1):61-70; discussion 70-1.

11. Lekovic GP, Gonzalez LF, Khurana VG, Spetzler RF Intraoperative rupture of brainstem cavernous malformation. Case report. Neurosurg Focus. 2006; 21(1):e14

12. Pozzati E, Marliani AF, Zucchelli M, Foschini MP, Dall'Olio M, Lanzino G. The neurovascular triad: mixed cavernous, capillary and venous malformations of the brainstem. J Neurosurg. 2007;107(6):1113-9.

13. Aiba T, Tanaka R, Koike T, Kameyama S, Takeda N, Komata T. Natural history of intracranial cavernous malformations. J Neurosurg. 1995;83(1):56-9.
14. Fritschi JA, Reulen HJ, Spetzler RF, Zabramski JM. Cavernous malformations of the brain stem. A review of 139 cases. Acta Neurochir (Wien). 1994;130(1-4): 35-46.

15. Sindou M, Yada J, Salord F. Functional results after microsurgical resection of brainstem cavernous malformations (retrospective study of a 12 patient series and review of the recent literature). Acta Neurochir (Wien). 2000;142(8):843-52; discussion 852-3.

16. Amin-Hanjani S, Ogilvy CS, Candia GJ, Lyons S, Chapman PH. Stereotactic radiosurgery for cavernous malformations: Kjellberg's experience with proton beam therapy in 98 cases at the Harvard Cyclotron. Neurosurgery. 1998;42(6):1229-36; discussion 1236-8.

17. Del Curling $0 \mathrm{Jr}$, Kelly DL Jr, Elster AD, Craven TE. An analysis of the natural history of cavernous angiomas. J Neurosurg. 1991;75(5):702-8.

18. Ferroli P, Sinisi M, Franzini A, Giombini S, Soleiro CL, Broggi GE. Brainstem cavernomas: Long-term results of microsurgical resection in 52 patients. Neurosurgery. 2005;56(6):1203-12; discussion 1212-4.

19. Porter RW, Detwiler PW, Sptzeler RF. Surgical technique for resection of cavernous malformations of the brain stem. Oper Tech Neurosurg. 2000; 3(2):124-30.

20. Kim DS, Park YG, Choi JU, Chung JU, Lee KC. An analysis of the natural history of cavernous malformations. Surg Neurol. 1997;48(1):9-17.

21. Kupersmith MJ, Kalish H, Epstein F, Yu G, Berenstein A, Woo H, et al. Natural history of brainstem cavernous malformations. Neurosurgery. 2001;48(1):4753; discussion 53-4.

22. Moriarity JL, Wetzeu M, Clatterbuck, Avedan S, Sheppard JM, HoenigRigamonti $\mathrm{K}$, et al. The natural history of cavernous malformations: a prospective study of 68 patients. Neurosurgery. 1999;44(6):1166-71; discussion 1172-3.

23. Moran NF, Fish DR, Kitchen Shorvon S, Kendall BE, Stevens F. Supratentorial cavernous haemangiomas and epilepsy: a review of the literature and case series. J Neurol Neurosurg Psychiatry. 1999;66(5):561-8.

24. Ziyal IM, Sekhar LN, Salas E, Sen C. Surgical management of cavernous malformations of the brain stem. Br J Neurosurg. 1999;13(4):366-75.

25. Bricolo A. Surgical management of intrinsic brain stem gliomas. Oper Tech Neurosurg. 2000;3(2):137-54.

26. Sakai N, Yamada H, Tanigawara T, Asano Y, Andoh T, Tanabe Y, et al. Surgical treatment of cavernous angioma involving the brainstem. Acta Neurochir (Wien). 1991;113(3-4):138-43.

27. Bouillot P, Dufour H, Roche PH, Lena G, Graziani N, Grisoli F. [Angiographically occult vascular malformations of the brain stem. A propos of 25 cases] Neurochirurgie. 1996;42(4-5):189-20; discussion 200-1. Article in French.

28. Steinberg GK, Chang SD, Gewirtz RJ, Lopes JR. Microsurgical resection of brainstem, thalamic and basal ganglia angiographically occult vascular malformations. Neurosurgery. 2000;46(2):260-70; discussion 270-1.

29. Cantore G, Missori G, Santoro A. Cavernous angiomas of the brain stem. Intra-axial anatomical pitfalls and surgical strategies. Surg Neurol. 1999; 52(1):84-93; discussion 93-4.

30. Kikuta K, Nozaki K, Takahashi JA, Miyamoto S, Kikuchi H, Hashimoto $N$. Postoperative evaluation of microsurgical resection for cavernous malformations of the brainstem. J Neurosurg. 2004;101(4):607-12. 